Abstract-The data collected through ichthyoplankton monitoring surveys provide valuable insight into the spawning dynamics of multiple species. Fish eggs, more than larvae, offer a more precise evaluation of species-specific spawning characteristics; however, egg collections are greatly underused because of the limitations associated with morphology-based identifications. In recent years, a new means of molecular identification, termed DNA barcoding, has made species identification readily available across a broad range of taxa. We used DNA barcoding to identify ethanol-preserved fish eggs collected during 2002-2012 along the northeastern U.S. continental shelf. A subsampling protocol was used to select 1603 unidentified eggs for analysis. DNA sequences were successfully obtained from $1495(93.26 \%)$ of these eggs, representing 50 species-many of which have either never before been identified to the species-level as eggs or have been identified previously only to a higher taxonomic level or during specific developmental egg stages. In comparison with past attempts at morphological identification, our molecular identifications comprise a broader diversity of eggs and provide a technique with high success rates of unambiguous identifications that is not sensitive to egg stage. Overall, this work shows that DNA barcoding of fish eggs is sufficiently advanced to be incorporated into long-term, regional-scale ichthyoplankton monitoring programs.

Manuscript submitted 6 April 2015. Manuscript accepted: 20 January 2016. Fish. Bull. 114:153-165 (2016).

Online publication date: 5 February 2016 . doi: 10.7755/FB.114.2.3

The views and opinions expressed or implied in this article are those of the author (or authors) and do not necessarily reflect the position of the National Marine Fisheries Service, NOAA.

\title{
Integrating DNA barcoding of fish eggs into ichthyoplankton monitoring programs
}

\author{
Leah A. Lewis 1 \\ David E. Richardson (contact author) ${ }^{1}$ \\ Evgeny V. Zakharov ${ }^{2}$ \\ Robert Hanner ${ }^{2}$ \\ Email address for contact author: david.richardson@noaa.gov \\ 1 Northeast Fisheries Science Center \\ National Marine Fisheries Service, NOAA \\ 28 Tarzwell Drive \\ Narragansett, Rhode Island 02882 \\ 2 Biodiversity Institute of Ontario \\ University of Guelph \\ Guelph, Ontario, Canada N1G 2W1
}

Pelagic eggs and larvae, collectively referred to as ichthyoplankton, are the life-history stages of fish that are most abundant within the marine epipelagic zone. Because of this prominence, a number of long-term ichthyoplankton monitoring programs have been established worldwide. The data collected through large-scale surveys provide fisheries-independent information on the spawning locations, times, and intensities of multiple species simultaneously. Ichthyoplankton data have also been used to estimate spawning stock biomass (Zeldis, 1993) and to develop long-term indices of abundance (Richardson et al., 2010a). In contrast to larvae, fish eggs provide a more precise means of evaluating the distribution and abundance of spawning fish populations because of the reduced cumulative influence of egg transport and mortality (Ouellet et al., 1997; Richardson et al., 2009). However, the number of identifiable egg characteristics is far fewer than the number of morphological features available for larval identification. Consequently, the major prerequisite-accurate species-level identification from eggs-remains an obstacle for the use of fish eggs in long-term monitoring and management programs.

Historically, the identification of fish eggs has been limited; illustrative guides often reference a small subsample of eggs from known parents or a small quantity of eggs collected during surveys and reared through the larval and juvenile stages (Colton and Marak ${ }^{1}$; Ahlstrom and Moser, 1980; Berrien and Sibunka ${ }^{2}$. On a broad scale, identifications traditionally have been based on morphological characteristics, including egg shape and diameter; number, size, and position of oil globules; width of the perivitelline space; nature of the egg yolk and chorion surface; and embryonic pigmentation.

${ }^{1}$ Colton, J. B., Jr., and R. R. Marak. 1969. Guide for identifying the common planktonic fish eggs and larvae of continental shelf waters, Cape Sable to Block Island. Bur. Commer. Fish., Biol. Lab. Ref. 69-9, $43 \mathrm{p}$.

2 Berrien, P. L., and J. D. Sibunka. 2006. A laboratory guide to the identification of marine fish eggs collected on the northeast coast of the United States, 1977-1994. U.S. Dep. Commer., NOAA, Northeast Fish. Sci. Cent. Ref. Doc. 06$21,162 \mathrm{p}$. 
Several of these features remain relatively constant throughout embryonic development; however, many characteristics are stage specific.

Overall, there are 4 significant limitations involved with morphological identifications. First, natural variation in morphological features of fish eggs, within a species, is common because of the effects of both maternal (Chambers and Leggett, 1996; Marteinsdottir and Steinarsson, 1998; Marteinsdottir and Begg, 2002) and environmental (Chambers and Leggett, 1996; Kucera et al., 2002) factors. Second, overlaps in morphological stages and similarities among the eggs of related and unrelated cryptic taxa can lead to incorrect identifications (Hyde et al., 2005; Berrien and Sibunka²; Gleason and Burton, 2012). Third, egg fixation in preservatives causes the loss of natural pigmentation and can obscure the developmental stage of an embryo (Valdez-Moreno et al., 2010). Finally, fixation can cause substantial egg shrinkage, a phenomenon that varies with preservative type and length of exposure (Hiemstra, 1962). In the Northwest Atlantic specifically, descriptions of eggs are lacking for more than $50 \%$ of fish species, and for those species for which there are descriptions, characteristics used to confidently identify field-collected specimens may be lacking for some or all stages of egg development (Kendall and Matarese, 1994).

Over the past decade, the use of molecular identification techniques has increased in response to the limitations associated with morphological identifications. For ichthyoplankton, these methods most frequently have involved the use of polymerase chain reaction (PCR) with species-specific primers and probes (Shao et al., 2002; Fox et al., 2005; Hyde et al., 2005; Carreon-Martinez et al., 2010) or the use of multiplex suspension bead arrays (Gleason and Burton, 2012); the former technique is even implemented onboard a research vessel (Hyde et al., 2005) and is used with formalin-preserved samples (Goodsir et al., 2008). Although these methods have been used successfully, the primary focus in these studies was to discriminate among a limited number of species. As a result, these methods rarely have proved versatile enough for use in fisheries monitoring programs or in large-scale egg surveys for which the identification of a wide diversity of species is necessary.

Around 2005, a new means of molecular identification was proposed with the goal of providing a universal approach to species identification. This concept, termed DNA barcoding, is based on the premise that the sequence diversity of a single mitochondrial gene, cytochrome $c$ oxidase subunit 1 (COI), is suitable for identifying most animal species (Hebert et al., 2003a, $2003 \mathrm{~b})$. Concerns over the use of a single locus to discriminate between closely allied species have been stressed since the DNA barcoding movement began; however, multiple studies have concluded that COI analysis is sufficient for species-level diagnoses. For example, this approach has been used successfully to barcode many Australian fish species (Ward et al., 2005) and to reveal overlooked marine species in the Indian
Ocean (Zemlak et al., 2009). The method of DNA barcoding has also been used to connect the egg and larval stages of marine species along the coastline of Yucatan, Mexico, to their adult counterparts (Valdez-Moreno et al., 2010) and for a large-scale larval fish study in the Straits of Florida (Richardson et al., 2007; Richardson et al., 2010b). To date, the DNA barcoding database for fishes (Barcode of Life Data System [BOLD], website, accessed March 2015) contains sequences of more than 175,000 specimens, representing more than 15,000 species (Ratnasingham and Hebert, 2007). These advances, coupled with a simultaneous decrease in cost (Richardson et al., 2007), have made it possible to consider the use of DNA barcoding for identification of fish eggs and to incorporate this approach into ecosystem monitoring programs.

In our study, we used DNA barcoding for the largescale identification of fish eggs. We sequenced DNA from eggs that were selected from a 10-year, multiseasonal archive of 456 ethanol-preserved samples that exists within the Northeast Fisheries Science Center (NEFSC), National Marine Fisheries Service, NOAA. Before 2000, fish eggs were identified by using morphological criteria. Since 2000, fish eggs collected through the NEFSC Ecosystem Monitoring (EcoMon) program have been counted but not identified because of a lack of personnel. The goals of this study are 1) to compare the species identifications, those produced from morphological versus molecular analyses of eggs, in terms of species diversity and taxonomic resolution and 2) to evaluate the feasibility of incorporation of DNA barcoding into long-term, regional-scale ichthyoplankton monitoring programs.

\section{Materials and methods}

\section{Sample collection and processing}

The NEFSC since 1971 has conducted ichthyoplankton surveys multiple times annually along the northeastern U.S. continental shelf between Cape Hatteras, North Carolina, and Nova Scotia, Canada (Richardson et al., 2010a). During these surveys, ichthyoplankton was sampled throughout the water column (to a depth within $5 \mathrm{~m}$ of the seafloor or to a maximum depth of $200 \mathrm{~m}$ ) with paired bongo samplers that had diameters of $61 \mathrm{~cm}$ and that were equipped with $333-\mu \mathrm{m}$ mesh nets. These samples had been preserved in formalin and-because formalin fixation causes significant damage to DNA, inhibiting amplification of the target COI gene-therefore were not considered suitable for this project (Hajibabaei et al., 2005). However, an additional bongo net, with a $20-\mathrm{cm}$ diameter, was included on the towing cable, just above the $61-\mathrm{cm}$ bongo net at about $15-20 \%$ of the sampling stations. Samples collected in the smaller net had been fixed and preserved in $95 \%$ ethanol (EtOH).

For our study, we used an archive of 456 EtOHpreserved ichthyoplankton samples that were collected 
during NEFSC surveys in the winter (January-February), late spring (May-June), late summer (August) and late autumn (November-December) over a 10-year period (2002-2012). Temperature and salinity profiles through the water column were collected with an SBE 19plus V2 SeaCAT $^{3}$ conductivity, temperature, and depth (CTD) profiler (Sea-Bird Electronics Inc., Bellevue, WA) attached to the tow wire above the bongo nets. Sea-surface temperatures (SSTs) were recorded during the upcast of the CTD profiler at the shallowest depth bin. Details on the collection localities and sampling dates were deposited within the publically available BOLD project file entitled "NIFEB: Fish Eggs Barcoding."

Ichthyoplankton samples preserved in $\mathrm{EtOH}$ were sorted manually for all fish eggs and larvae in the laboratory. Fish eggs were removed from a sample and transferred to $7-\mathrm{mL}$ (2-dram) glass vials filled with 95\% EtOH. No morphological identifications were attempted during or after the sorting procedure.

\section{Subsampling of eggs for molecular identification}

The total number of eggs collected in all of the samples exceeded our molecular processing capacity. For that reason, we implemented a 2 -stage subsampling procedure designed to determine the diversity of eggs within each sample. For the first stage of subsampling, a maximum number of 10 eggs were randomly selected for identification from each sorted sample. Individual eggs were first digitally photographed and measured (in millimeters) with Nikon imaging software (NIS-Elements BR, vers. 2.3, Nikon Instruments Inc., Melville, $\mathrm{NY}$ ) and a color digital camera (Nikon DXM-1200C) mounted on a stereo microscope (Nikon SMZ1500) under both reflected and transmitted light. Fish eggs were then placed in 96-well plates with one egg and one drop of $95 \% \mathrm{EtOH}$ per well. A negative control well also was included on each plate.

Of the initial 456 samples, 73 contained $>10$ eggs and were subjected to a second round of subsampling that that was based on both egg measurements and the results from the initial round of molecular identifications. For this second round of subsampling, we measured the diameter of the remaining unidentified eggs in the samples. Histograms of egg diameters within 0.05-mm-diameter bins were developed for each sample, and additional eggs were chosen for molecular identification from any 0.05 -mm-diameter bin that either did not include an egg identified during the first round of molecular identification or contained a high number of eggs and multiple species of eggs. The intent of this second round of subsampling was to ensure that the diversity of eggs within a sample was identified, while avoiding repeatedly sequencing the same species of egg at the same sampling station. As a result of the

\footnotetext{
${ }^{3}$ Mention of trade names or commercial companies is for identification purposes only and does not imply endorsement by the National Marine Fisheries Service, NOAA.
}

opaqueness of ethanol-preserved eggs, we did not use any other morphological feature (other than egg diameter) for subsampling.

To speed up the subsampling process, we developed an automated egg measuring graphical user interface with the Image Processing Toolbox in MATLAB, vers. R2012A (The MathWorks Inc., Natick, MA). Up to 40 eggs at a time were digitally photographed on an acrylic plate containing a rectangular well specifically sized for the digital image taken at $3 \times$ magnification (Fig. 1A). A black and white threshold was then manually applied to each image (Fig. 1B) and then the Hough transformation was applied to the thresholded image (Fig. 1C). The Hough transformation is designed to find circles within an image, including circles with a broken outer border. The interface that we developed contained slider bars that allow a user to optimize the black and white thresholding process for an individual picture, as well as the minimum circle quality used in the find circle algorithm. Finally, manual editing of the automatically measured circular egg was performed, and measurements of ovoid eggs were added (Fig. 1D). The result of this procedure was a text file that contained the diameters of each measured circular egg or the long axis and short axis of ovoid eggs.

Egg abundances are reported as the number of eggs per $10 \mathrm{~m}^{2}$ of water. To account for the subsampling, each station's total egg abundance within each 0.05$\mathrm{mm}$ egg-diameter bin was first calculated. For each diameter bin, species were assigned in proportion to the available molecular identifications within that bin with a procedure analogous to the use of age-length keys. Oval eggs, which corresponded to 1 of 3 anchovy species, were excluded from this process because they could be assigned to species based solely on shape (long axis:short axis) and size.

\section{Molecular identification protocol}

Prepared plates were sent by mail to the University of Guelph's Canadian Centre for DNA Barcoding, a molecular identification laboratory with a proven success rate and developed database capable of accommodating large data output associated with high-throughput DNA sequencing. Key sample data, including specimen collection information, voucher image files, and a plate record (sample array details for each plate) were sent electronically to the Canadian Centre for DNA Barcoding. This information was organized within the BOLD online database, and each COI barcode sequence was connected to its source specimen following DNA barcode analysis.

Standard DNA barcoding protocols were followed for all analytical steps, including DNA extraction, PCR, and DNA sequencing. Submitted samples were subjected to overnight lysis in a lysis buffer with proteinase $\mathrm{K}$ (Thermo Fisher Scientific Inc., Waltham, MA), followed by DNA extraction onto a glass fiber membrane (Pall Corp., Port Washington, NY) by using an automated protocol (Ivanova et al., 2006). A barcode region of 658 


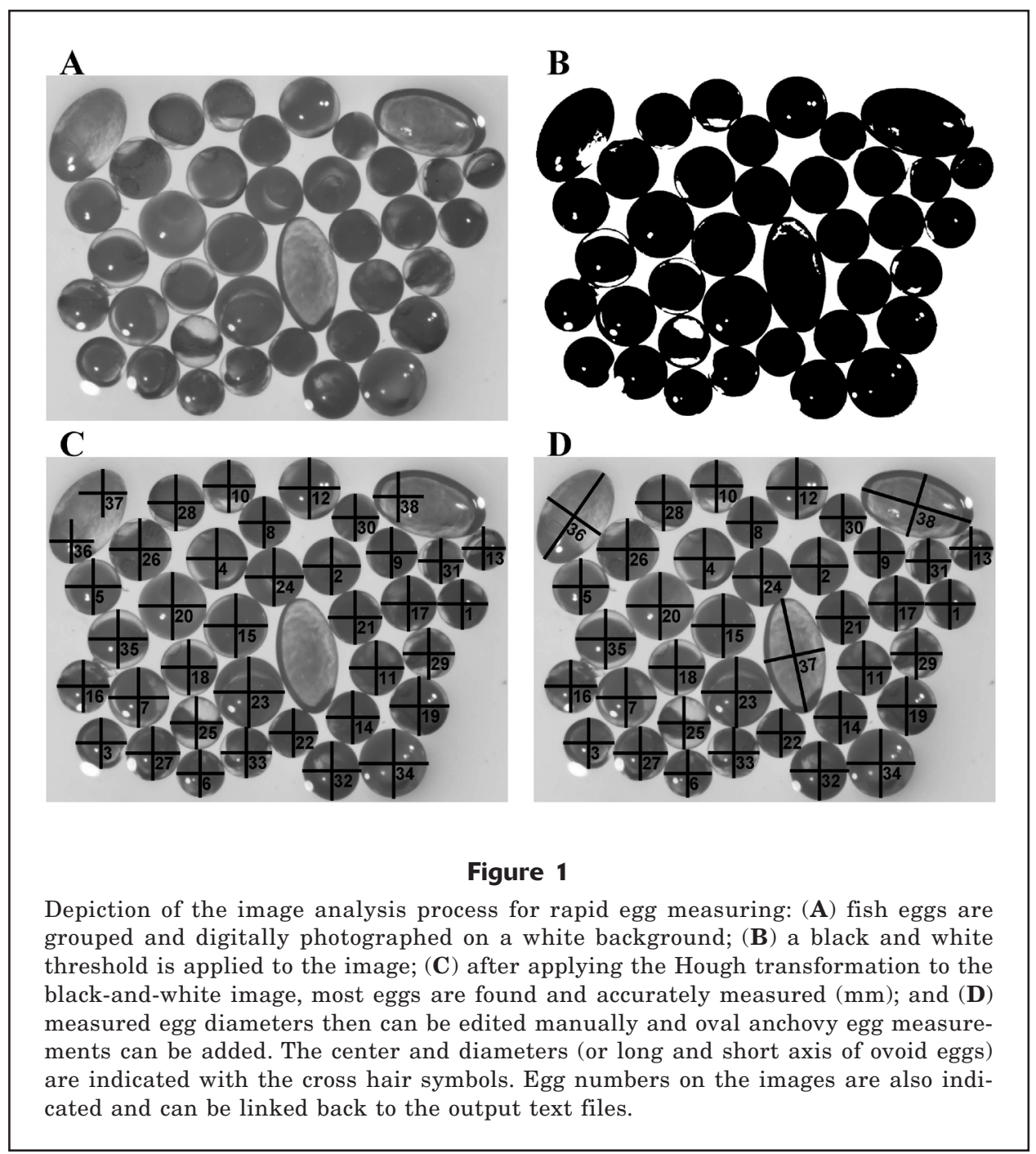

base pairs (bp) of the mitochondrial gene COI was amplified with primer cocktails C_FishF1t1 + C_FishR1t1 and AquaF2 + C_VR1LRt1 (Ivanova et al., 2012). The PCR mix included $6.25 \mu \mathrm{L}$ of $10 \%$ trehalose, $1.25 \mu \mathrm{L}$ $10 \times$ PCR buffer, $0.625 \mu \mathrm{L}(2.5 \mathrm{mM}) \mathrm{MgCl}_{2}, 0.125 \mu \mathrm{L}(10$ $\mu \mathrm{M})$ forward and reverse primer cocktail, $0.625 \mu \mathrm{L}(10$ $\mathrm{mM}$ ) deoxyribonucleotide triphosphates (dNTPs), 0.625 $\mu \mathrm{L}$ Platinum Taq polymerase (Thermo Fisher Scientific Inc.), $3 \mathrm{ul} \mathrm{H}_{2} \mathrm{O}$ and $1 \mathrm{\mu L}$ of DNA template.

The following cycle conditions were used to run PCRs: $1 \mathrm{~min}$ at $94^{\circ} \mathrm{C}$ followed by 5 cycles of $30 \mathrm{~s}$ at $94^{\circ} \mathrm{C} ; 40 \mathrm{~s}$ at $55^{\circ} \mathrm{C}$ and $1 \mathrm{~min}$ at $72^{\circ} \mathrm{C}$, followed by 35 cycles of $30 \mathrm{~s}$ at $94^{\circ} \mathrm{C} ; 40 \mathrm{~s}$ at $55^{\circ} \mathrm{C}$, and $1 \mathrm{~min}$ at $72^{\circ} \mathrm{C}$, with a final extension of $10 \mathrm{~min}$ at $72^{\circ} \mathrm{C}$. PCR products were visualized by using agarose gel electrophoresis with buffer-less precast E-Gel system (Thermo Fisher Scientific Inc.). Successful amplicons were cycle sequenced by using BigDye Terminator vers. 3.1 (Thermo Fisher Scientific Inc.) and the manufacturer's recommended protocols. Sequencing products with incorporated BigDye Terminator were purified with the bead cleanup method of solid phase reversible immobilization (SPRI; Agencourt Bioscience Corp., Beverly, MA) and were analyzed on an Applied Biosystems 3730xl DNA Sequencer (Thermo Fisher Scientific Inc.).

Applied Biosystems trace files for each specimen were assembled into contigs (contiguous sequences of DNA) with the use of Codon Code Aligner software (CodonCode Corp., Centerville, MA). Resulting consensus sequences and trace files were uploaded to the NIFEB project file on the BOLD data system.

\section{Sequence analysis and species identification}

For a comparison of sequences and species identification, we used the BOLD system and its analytical tools. Neighbor-joining taxonomic identification trees of Kimura 2-parameter distance were built on the basis of COI-5P ( $5^{\prime}$ region) nucleotide sequence data to provide a graphic representation of the pattern of divergence between species (Saitou and Nei, 1987). Regardless of bp length, medium- and high-quality COI sequences 
were queried against the web-based BOLD database. We used a threshold of a $99 \%$ match to assign a match to species. For specimens for which the BOLD engine failed to find a match, sequences were applied directly to the Standard Nucleotide BLAST on GenBank (National Center for Biotechnology Information, website). Sequence data, electropherograms, and primer details for specimens are available within the completed NIFEB project file on BOLD. Sequence data was also submitted to GenBank (accession numbers: KP110771KP112146). Low-quality sequences can often provide sufficient information to identify a sample to species; however, we chose to exclude them from subsequent analyses to ensure the reliability of our database.

\section{Data analysis}

Standard box plots were used to present the SST range and size range of each species of egg that we collected and barcoded. In addition, for species that were identified from at least 15 stations, we further sought to determine the correlation between egg measurement and the SST at sampling stations. The graphical and statistical tools available through RStudio (RStudio, Boston, MA) were used to perform linear regression analysis on the effects of SST on egg diameter. Notably, the process of measuring and photographing eggs did not occur for the first 2 plates (190 eggs) of samples; therefore, these eggs were excluded from the analyses where egg diameter was used.

For SST in our analyses, it was assumed that the eggs collected at a station were located above the thermocline or that the waters were well mixed. During the late fall (November-December) and winter (January-February), the water column in our region is well mixed and, therefore, the vertical distribution of eggs has little effect on the temperature they experience. The same is true year-round in the shallow areas on Georges Bank. However, during the late spring (MayJune) and summer (August), the water column in our region is stratified. Typically, fish eggs collected in ichthyoplankton sampling are positively buoyant and concentrate in the upper water column, but there are exceptions (Conway et al., 1997). Because our sampling was not vertically stratified, we relied on SST as the best estimate of the temperature experienced by the eggs.

\section{Results}

In total, DNA was sequenced from 1603 unidentified fish eggs collected at 456 stations and that were processed as ethanol-preserved ichthyoplankton samples. Of these eggs, $93.26 \%$ (1495 eggs) were sequenced successfully, providing medium- or high-quality barcodes suitable for species-level identifications. Of the 108 unidentified eggs, 60 eggs $(3.74 \%)$ failed both first- and second-round sequencing attempts, and 8 eggs $(0.50 \%)$ were flagged because of contamination that occurred at an unknown point during the barcoding process. The remaining 40 eggs $(2.50 \%)$ produced low-quality sequences. In many cases, identifications could be assigned to these low-quality sequences; however, we chose to be conservative and classify these eggs as unidentified. Sequence analysis revealed that the 1495 successfully sequenced fish eggs represented 50 identified species, 49 of which could be definitively matched to species-level barcodes, and 1 taxa with 12 eggs produced a match to a specimen identified previously only at the family level (Engraulidae) on GenBank (Table 1).

The number of identified eggs per species ranged from 1 to 196. The 4 most frequently identified eggs were those of silver hake (Merluccius bilinearis), fourspot flounder (Hippoglossina oblonga), Gulf Stream flounder (Citharichthys arctifrons), and red hake (Urophycis chuss); together, these 4 species accounted for more than $45 \%$ of all successful barcode identifications. In comparison with previous morphological attempts at fish egg identification in the northeastern United States (Colton and Marak ${ }^{1}$; Berrien and Sibunka ${ }^{2}$ ), the eggs of our barcoded species fit into 3 general categories: category I (6 of our 50 species) are eggs that have never before been identified to the species-level as eggs; category II (33 species) describes eggs that have historically been identifiable only at higher taxonomic levels (genus or family) or at the species level during specific stages of development (i.e., eggs at mid to late stages); and category III (11 species) contains eggs that are well described and can be identified confidently to species level through the use of morphological criteria at all stages of development (Table 1).

Overall, egg abundances varied significantly with sampling season (Fig. 2, A-D). In aggregate, the greatest abundances and diversity of eggs were found during the sampling periods of late summer (August) and late spring (May-June). The lowest abundance of eggs was encountered in late autumn (November-December), and the lowest diversity was found in the winter (January-February). Of the 50 species with eggs identified, 25 species had eggs collected during multiple seasons (indicative of cross-seasonal or elongated spawning). The most frequently observed cross-seasonal collection pattern was between late spring and late summer; however, the eggs of Atlantic cod (Gadus morhua) and pollock (Pollachius virens) were collected throughout late autumn and winter. The eggs of only 1 species, offshore hake (Merluccius albidus), were collected in all 4 sampling seasons. The 3 most abundant species of eggs identified, with all seasons combined, were red hake, Gulf Stream flounder, and silver hake (Table 1).

The successfully barcoded fish eggs were collected at a wide range of temperatures; recorded SSTs ranged from $3.11^{\circ} \mathrm{C}$ to $27.02^{\circ} \mathrm{C}$ (Table 1). In general, the SST range of an individual species was much narrower (Fig. 3). Eggs of haddock (Melanogrammus aeglefinus), American plaice (Hippoglossoides platessoides), and spotted pikeconger (Hoplunnis tenuis) were collected at the lowest average SSTs $\left(4.63^{\circ} \mathrm{C}, 7.15^{\circ} \mathrm{C}\right.$, and $7.29^{\circ} \mathrm{C}$, 


\section{Table 1}

Results from the molecular identification of fish eggs with the use of DNA barcoding; number of identified eggs per species $(N)$ and the number of stations (no. sta.) at which eggs of each species were found. Calculated abundances (number of eggs per $10 \mathrm{~m}^{2}$ of water) by season for each species and the identification category (cat.) of the eggs for each species are also included: category I eggs have never before been identified to species-level as eggs; category II eggs have been identified previously only at higher taxonomic levels or to species-level at specific stages of development; and category III eggs are well-described and can be confidently identified to species-level at all stages of development. For each species, the mean egg diameter and size range are listed as well, along with the mean and range of collection-day sea-surface temperatures (SSTs).

\begin{tabular}{|c|c|c|c|c|c|c|c|c|c|c|c|}
\hline \multirow[b]{2}{*}{ Species } & \multirow[b]{2}{*}{ Family } & \multirow[b]{2}{*}{ Common name } & \multirow[b]{2}{*}{$N$} & \multirow[b]{2}{*}{$\begin{array}{l}\text { No. } \\
\text { sta. }\end{array}$} & \multicolumn{4}{|c|}{ Calculated abundances } & \multirow[b]{2}{*}{ Cat. } & \multirow[b]{2}{*}{$\begin{array}{c}\text { Mean } \\
\text { diameter }(\mathrm{mm})\end{array}$} & \multirow[b]{2}{*}{$\begin{array}{c}\text { Mean } \\
\text { SST }\left({ }^{\circ} \mathrm{C}\right)\end{array}$} \\
\hline & & & & & $\begin{array}{c}\text { Jan- } \\
\text { Feb }\end{array}$ & $\begin{array}{l}\text { May- } \\
\text { Jun }\end{array}$ & Aug & $\begin{array}{l}\text { Nov- } \\
\text { Dec }\end{array}$ & & & \\
\hline Merluccius bilinearis & Merlucciidae & silver hake & 196 & 59 & 0 & 18.2 & 92.3 & 2.1 & III & $0.92(0.73-1.06)$ & $15.3(8.6-23.2)$ \\
\hline Hippoglossina oblonga & Paralichthyidae & fourspot flounder & 184 & 72 & 0 & 11.0 & 29.2 & 0 & II & $0.93(0.76-1.08)$ & $17.4(9.0-26.3)$ \\
\hline Citharichthys arctifrons & Paralichthyidae & Gulf Stream flounder & 153 & 45 & 0 & 23.9 & 89.4 & 0 & II & $0.72(0.59-0.83)$ & $19.2(9.4-27.0)$ \\
\hline \multirow[t]{2}{*}{ Urophycis chuss } & Phycidae & red hake & 144 & 53 & 0 & 4.7 & 210.2 & 0.3 & II & $0.73(0.62-0.81)$ & $18.0(10.9-26.3)$ \\
\hline & & Unidentified & 108 & 64 & 10 & 5.6 & 18.9 & 8.5 & & $1.02(0.57-1.71)$ & $13.4(3.1-25.9)$ \\
\hline Scophthalmus aquosus & Scophthalmidae & windowpane & 81 & 29 & 0 & 11.3 & 10.1 & 0.8 & II & $1.00(0.85-1.17)$ & $13.2(6.4-17.7)$ \\
\hline Limanda ferruginea & Pleuronectidae & yellowtail flounder & 80 & 22 & 0 & 54.7 & 0.8 & 0 & II & $0.80(0.69-0.94)$ & $9.4(5.4-15.9)$ \\
\hline Peprilus triacanthus & Stromateidae & butterfish & 52 & 22 & 0 & 14.7 & 10.3 & 0 & II & $0.73(0.57-0.85)$ & $18.6(11.9-25.9)$ \\
\hline Paralichthys dentatus & Paralichthyidae & summer flounder & 50 & 16 & 0 & 0.7 & 0 & 16.0 & III & $0.96(0.76-1.10)$ & $15.0(11.9-17.5)$ \\
\hline Prionotus carolinus & Triglidae & northern searobin & 49 & 10 & 0 & 0 & 22.7 & 0.4 & II & $0.98(0.87-1.11)$ & $24.7(16.1-26.8)$ \\
\hline Gadus morhua & Gadidae & Atlantic cod & 47 & 15 & 15.5 & 0 & 0 & 9.1 & II & $1.34(1.15-1.71)$ & $8.6(3.1-11.0)$ \\
\hline Tautogolabrus adspersus & Labridae & cunner & 45 & 17 & 0 & 23.3 & 1.6 & 0.0 & II & $0.88(0.77-1.00)$ & $13.8(9.0-20.4)$ \\
\hline Melanogrammus aeglefinus & Gadidae & haddock & 44 & 10 & 41.0 & 1.5 & 0 & 0 & II & $1.46(1.25-1.62)$ & $4.6(3.1-10.2)$ \\
\hline Enchelyopus cimbrius & Lotidae & fourbeard rockling & 35 & 19 & 0 & 14.1 & 1.0 & 0 & II & $0.75(0.65-0.83)$ & $11.0(7.6-15.3)$ \\
\hline Anchoa mitchilli & Engraulidae & bay anchovy & 34 & 6 & 0 & 54.7 & 0 & 0 & III & $0.91(0.78-1.05)$ & $18.2(12.3-19.9)$ \\
\hline Pollachius virens & Gadidae & pollock & 34 & 10 & 1.2 & 0 & 0 & 21.0 & III & $1.14(0.93-1.29)$ & $9.5(5.9-11.0)$ \\
\hline Etropus microstomus & Paralichthyidae & smallmouth flounder & 23 & 9 & 0 & 4.5 & 2.0 & 0.0 & II & $0.65(0.57-0.73)$ & $19.8(16.2-26.7)$ \\
\hline Scomber scombrus & Scombridae & Atlantic mackerel & 22 & 14 & 0 & 7.9 & 0.0 & 0.0 & III & $1.14(1.06-1.22)$ & $11.2(8.2-12.8)$ \\
\hline Merluccius albidus & Merlucciidae & offshore hake & 19 & 9 & 0.4 & 2.0 & 2.9 & 0.6 & III & $1.13(1.08-1.24)$ & $17.9(11.1-25.1)$ \\
\hline Glyptocephalus cynoglossus & Pleuronectidae & witch flounder & 18 & 12 & 0 & 3.2 & 2.1 & 0 & II & $1.14(1.06-1.29)$ & $11.0(8.2-16.7)$ \\
\hline Tautoga onitis & Labridae & tautog & 17 & 7 & 0 & 5.5 & 0.4 & 0 & II & $0.99(0.86-1.07)$ & $15.0(9.4-24.8)$ \\
\hline Urophycis regia & Phycidae & spotted hake & 16 & 7 & 1.0 & 0 & 0.9 & 1.8 & II & $0.74(0.67-0.82)$ & $17.0(7.3-25.1)$ \\
\hline Micropogonias undulatus & Sciaenidae & Atlantic croaker & 15 & 2 & 0 & 0 & 19.3 & 0 & II & $0.72(0.65-0.77)$ & $26.0(25.9-26.0)$ \\
\hline Brosme brosme & Lotidae & cusk & 15 & 7 & 0 & 6.4 & 0.5 & 0 & II & $1.25(1.08-1.42)$ & $9.5(5.4-12.9)$ \\
\hline Anchoa hepsetus & Engraulidae & striped anchovy & 15 & 6 & 0 & 5.5 & 0 & 0 & III & $1.44(1.23-1.64)$ & $19.5(18.2-20.4)$ \\
\hline \multirow{2}{*}{ Astroscopus y-graecum } & Uranoscopidae & southern stargazer & 13 & 9 & 0 & 0 & 2.9 & 0 & II & $1.60(1.40-1.81)$ & $24.1(16.2-27.0)$ \\
\hline & Engraulidae & anchovy spp. & 12 & 3 & 0 & 0 & 55.2 & 0 & I & $0.75(0.68-0.84)$ & $25.6(23.3-26.0)$ \\
\hline Prionotus evolans & Triglidae & striped searobin & 11 & 5 & 0 & 2.4 & 0.2 & 0 & II & $1.10(1.01-1.18)$ & $16.4(12.3-25.1)$ \\
\hline Centropristis striata & Serranidae & black sea bass & 7 & 5 & 0 & 0.5 & 1.4 & 0 & II & $0.86(0.77-0.97)$ & $23.4(20.1-26.8)$ \\
\hline Orthopristis chrysoptera & Haemulidae & pigfish & 7 & 1 & 0 & 0 & 0 & 0 & II & no data & $19.5(19.5)$ \\
\hline Menticirrhus americanus & Sciaenidae & southern kingfish & 7 & 3 & 0 & 0.9 & 0.1 & 0 & I & $0.77(0.76-0.79)$ & $19.8(18.7-24.1)$ \\
\hline Brevoortia tyrannus & Clupeidae & Atlantic menhaden & 5 & 3 & 0.5 & 0.7 & 0 & 0 & III & $1.35(1.17-1.57)$ & $12.3(3.1-15.2)$ \\
\hline Trichiurus lepturus & Trichiuridae & Atlantic cutlassfish & 5 & 1 & 0 & 0 & 0.9 & 0 & I & $1.63(1.57-1.66)$ & $26.8(26.8)$ \\
\hline Ophichthus cruentifer & Ophichthidae & margined snake eel & 5 & 4 & 0 & 0 & 3.3 & 0 & III & $2.43(2.29-2.52)$ & $22.0(18.1-25.2)$ \\
\hline Sarda sarda & Scombridae & Atlantic bonito & 4 & 1 & 0 & 0 & 0 & 0 & II & $1.26(1.26)$ & $19.0(19.0)$ \\
\hline Auxis rochei & Scombridae & bullet tuna & 4 & 2 & 0 & 0 & 1.2 & 0 & II & $0.86(0.79-0.89)$ & $25.7(25.0-26.3)$ \\
\hline Hippoglossoides platessoides & Pleuronectidae & American plaice & 3 & 3 & 0.4 & 0.7 & 0 & 0 & III & $2.05(2.00-2.13)$ & $7.1(3.1-12.9)$ \\
\hline Pomatomus saltatrix & Pomatomidae & bluefish & 3 & 2 & 0 & 0 & 1.6 & 0 & II & $0.72(0.72)$ & $21.3(19.5-24.9)$ \\
\hline Symphurus diomedeanus & Cynoglossidae & spottedfin tonguefish & 3 & 2 & 0 & 0 & 0 & 0.7 & II & $0.75(0.71-0.78)$ & $15.8(15.7-15.8)$ \\
\hline Cynoscion regalis & Sciaenidae & weakfish & 3 & 1 & 0 & 2.6 & 0 & 0 & II & $0.80(0.76-0.82)$ & $19.9(19.9)$ \\
\hline Menticirrhus saxatilis & Sciaenidae & northern kingfish & 2 & 1 & 0 & 0 & 0 & 0 & II & no data & $19.0(19.0)$ \\
\hline Engraulis eurystole & Engraulidae & silver anchovy & 2 & 1 & 0 & 0 & 0 & 0 & III & $1.32(1.32)$ & $19.5(19.5)$ \\
\hline Lopholatilus chamealeonticeps & Malacanthidae & tilefish & 2 & 1 & 0 & 0 & 0.7 & 0 & II & $1.29(1.27-1.30)$ & $25.1(25.1)$ \\
\hline Urophycis tenuis & Phycidae & white hake & 2 & 1 & 0 & 1.1 & 0 & 0 & II & $0.77(0.76-0.78)$ & $22.0(22.0)$ \\
\hline Symphurus plagiusa & Cynoglossidae & blackcheek tonguefish & 1 & 1 & 0 & 0 & 0.9 & 0 & II & $0.57(0.57)$ & $26.0(26.0)$ \\
\hline Lepophidium profundorum & Ophidiidae & fawn cusk-eel & 1 & 1 & 0 & 0 & 0 & 0.4 & II & $1.01(1.01)$ & $13.1(13.1)$ \\
\hline Caulolatilus microps & Melacanthidae & grey tilefish & 1 & 1 & 0 & 0 & 0 & 0 & I & no data & $17.6(17.6)$ \\
\hline Sciaenops ocellatus & Sciaenidae & red drum & 1 & 1 & 0 & 0 & 0.2 & 0.0 & II & $0.80(0.80)$ & $26.8(26.8)$ \\
\hline Archosargus probataocephalus & Sparidae & sheepshead & 1 & 1 & 0 & 0 & 0 & 0 & II & no data & $19.5(19.5)$ \\
\hline Hoplunnis tenuis & Nettastomatidae & spotted pikeconger & 1 & 1 & 0.5 & 0 & 0 & 0 & I & $2.19(2.19)$ & $7.3(7.3)$ \\
\hline \multirow{2}{*}{ Hemanthias aureorubens } & Serranidae & streamer bass & 1 & 1 & 0 & 0 & 0 & 0.3 & I & $0.72(0.72)$ & $15.8(15.8)$ \\
\hline & & Grand total: & 1603 & & 70.2 & 282.3 & 583.2 & 61.9 & & & \\
\hline
\end{tabular}



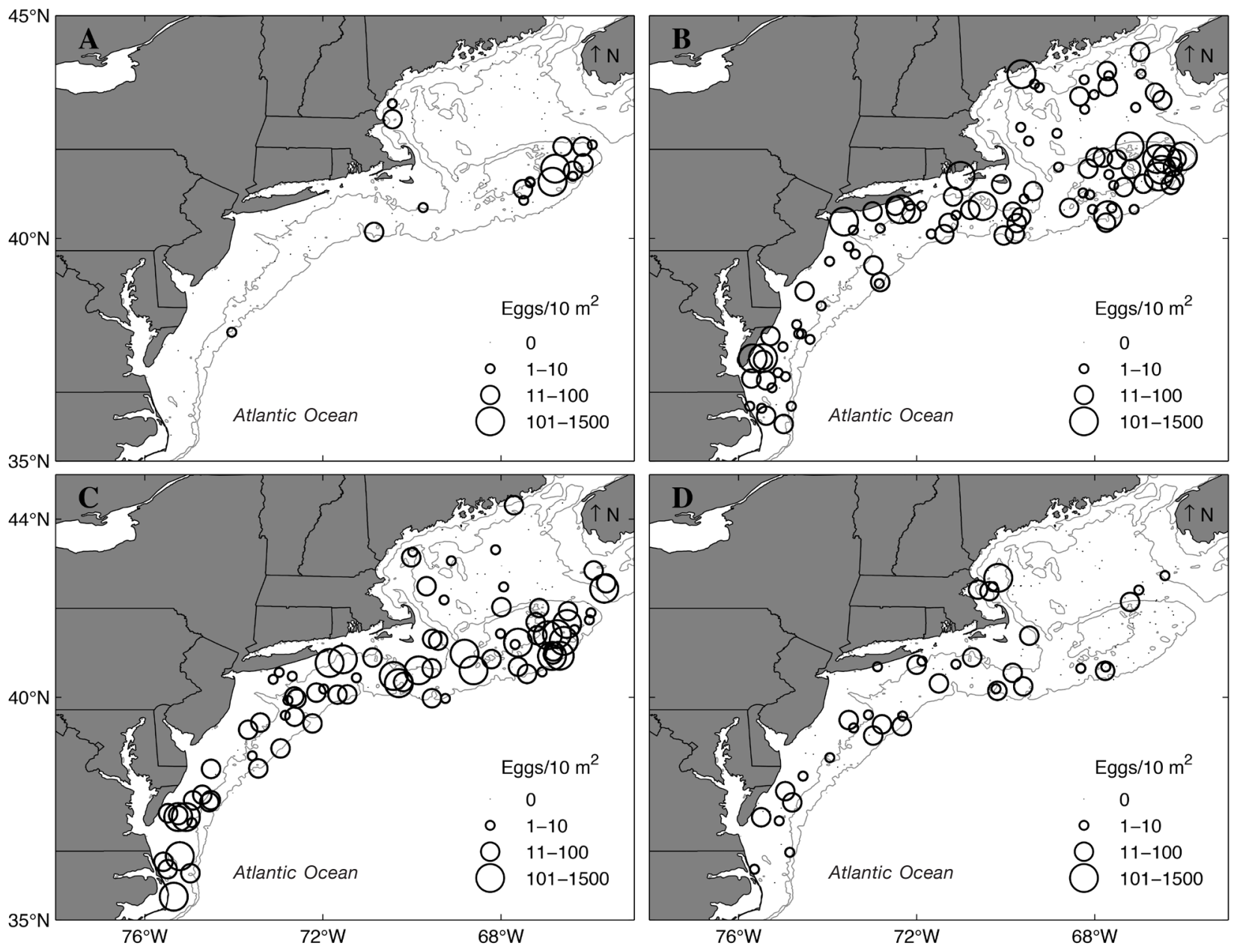

Figure 2

Maps showing the locations of calculated egg abundances, reported as the number of eggs per $10 \mathrm{~m}^{2}$ of water, based on sort counts and station haul factor values from ichthyoplankton samples collected along the northeastern U. S. continental shelf during 2002-2012 by the NOAA Northeast Fisheries Science Center during its 4 sampling seasons of (A) winter (January-February), (B) late spring (May-June), (C) late summer (August), and (D) late autumn (November-December).

respectively), and the singular eggs of Atlantic cutlassfish (Trichiurus lepturus) and red drum (Sciaenops ocellatus) were each collected at the highest recorded temperature of $26.84^{\circ} \mathrm{C}$.

Egg size also varied significantly between species; measured diameters of the successfully barcoded eggs ranged from $0.57 \mathrm{~mm}$ to $2.52 \mathrm{~mm}$ (Fig. 4). The eggs of blackcheek tonguefish (Symphurus plagiusa), smallmouth flounder (Etropus microstomus), and butterfish (Peprilus triacanthus) were smallest on average; each species had one egg with a measured diameter of 0.57 $\mathrm{mm}$. On the opposite end of the scale, eggs of margined snake eel (Ophichthus cruentifer) were the largest, with an average egg diameter of $2.43 \mathrm{~mm}(N=5)$ (Table 1 ). The egg size range of Atlantic cod was the greatest with a difference of $0.56 \mathrm{~mm}$ separating the smallest and largest diameter measurements $(N=47)$. Diameters for the various species of identified anchovies were based on long-axis measurements because eggs of these species are naturally ovoid in shape.

For barcoded species that were identified from at least 15 stations, egg measurement and collection data were further analyzed to determine correlations between egg size and SST. Of the 11 species that met the 15 -station requirement and were tested, 5 species displayed significant trends $(P<0.05$ or $5 \%)$ between SST and average egg diameter (Table 2, Fig. 5, A-E), with yellowtail flounder (Limanda ferruginea) being the only species to illustrate a positive correlation between SST and egg diameter.

\section{Discussion}

One of the primary goals for this study was to compare our results from the molecular identification of 


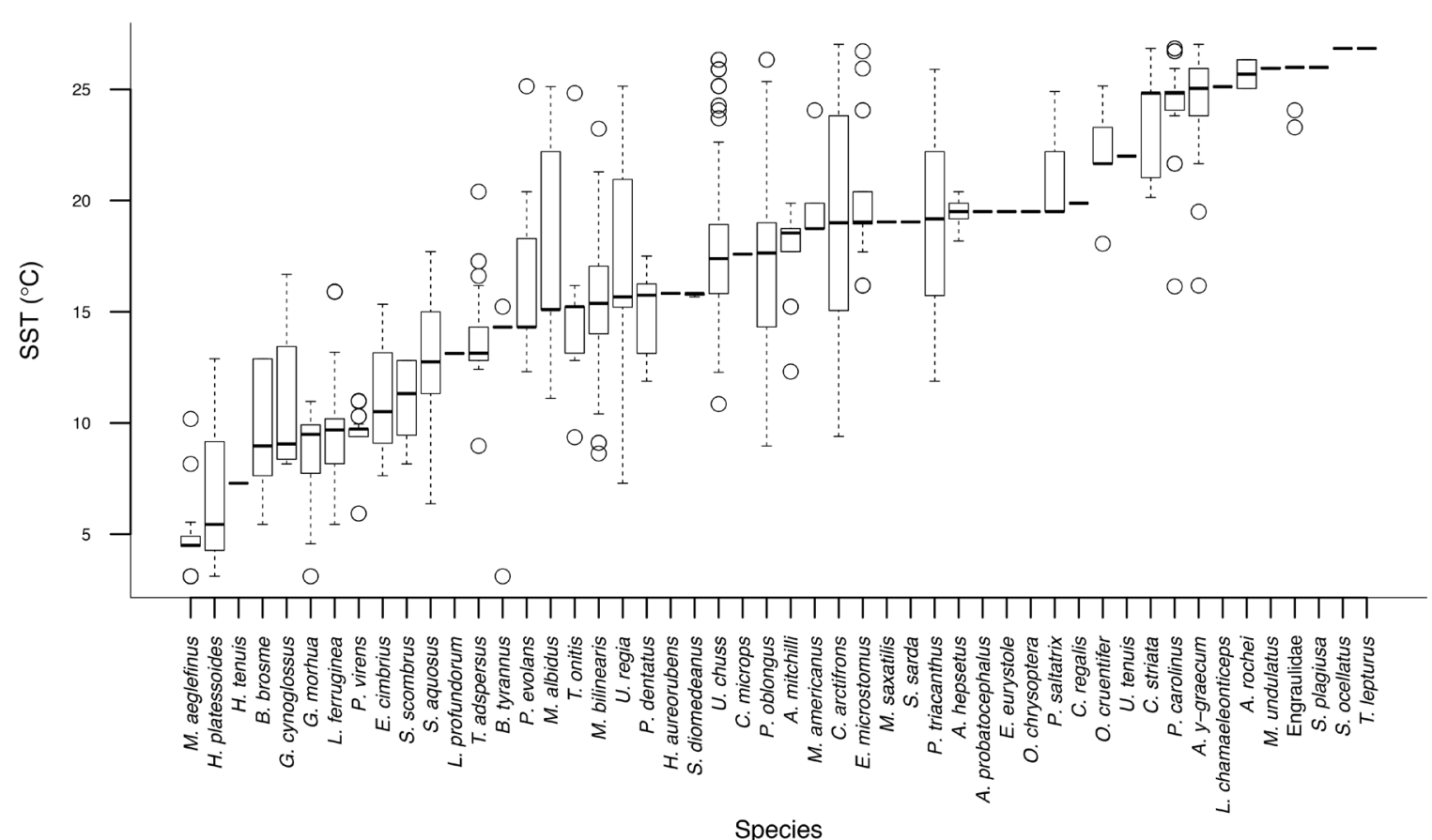

Figure 3

Box plot illustrating the ranges of sea-surface temperature (SST) (in degrees Celsius) for the collection day for each of the 50 species of eggs that were successfully identified by using DNA barcoding. For species with more than 1 identified egg a box is drawn to include SSTs within the first and third quartiles; dashed whisker lines extend from the box to the minimum and maximum SST observed. The median SST for the collection day for each species is marked by a thick, dark horizontal band, and outlying SSTs are indicated with open circles.

fish eggs with previous results from morphological identifications. Because of several inherent differences in methods, we were unable to conduct a direct comparison between morphological and molecular identification from the same specimens. Morphological egg identifications at the NEFSC were discontinued in the early 2000 s because the involved individuals retired. Moreover, these identifications were performed on formalin-preserved eggs, which are less suitable for use in a DNA-barcoding approach. Specialized techniques have been developed to allow for the molecular identification of formalin-preserved material, but these procedures typically are more costly than our approach and use only very short DNA fragments. In contrast to formalin-preserved eggs, ethanol-preserved eggs can be readily identified with molecular techniques. However, ethanol denatures fish egg proteins, obscuring many of the internal morphological characters used for staging and identification. For this reason, the only morphological character we recorded for each molecularly identified egg was egg diameter; other characters could not clearly be resolved on all specimens. For some species, particularly those species with a large perivitelline space, such as Atlantic menhaden (Brevoortia tyrannus), egg shrinkage appears to differ between ethanol and formalin preservation, limiting compari- sons of egg-size ranges among our data and historical data. Because of the impossibility of making direct specimen-by-specimen comparisons, we focused our analyses on broader patterns of species composition and diversity.

Overall, our molecular identifications represented a broader diversity of eggs than did the morphological identifications, including unexpectedly encountered taxa, such as white hake (Urophycis tenuis), which was not thought to spawn in the Gulf of Maine, as well as taxa that have previously been considered unidentifiable. In the past, many egg identifications were possible only to the genus level, whereas $>93 \%$ of our barcoded fish eggs were identifiable to species; of our successfully barcoded eggs, 12 were identifiable only to the family level (Engraulidae) owing simply to the fact that this particular species has not yet been barcoded. Furthermore, our approach provides a technique with high success rates of unambiguous identifications and that is not sensitive to developmental egg stages. Historically, for morphological egg identifications, a large proportion of eggs was assigned to species in part by using nondiagnostic criteria, such as the presence of late-stage eggs of a species in the sample or the time and location of collection of the sample. 


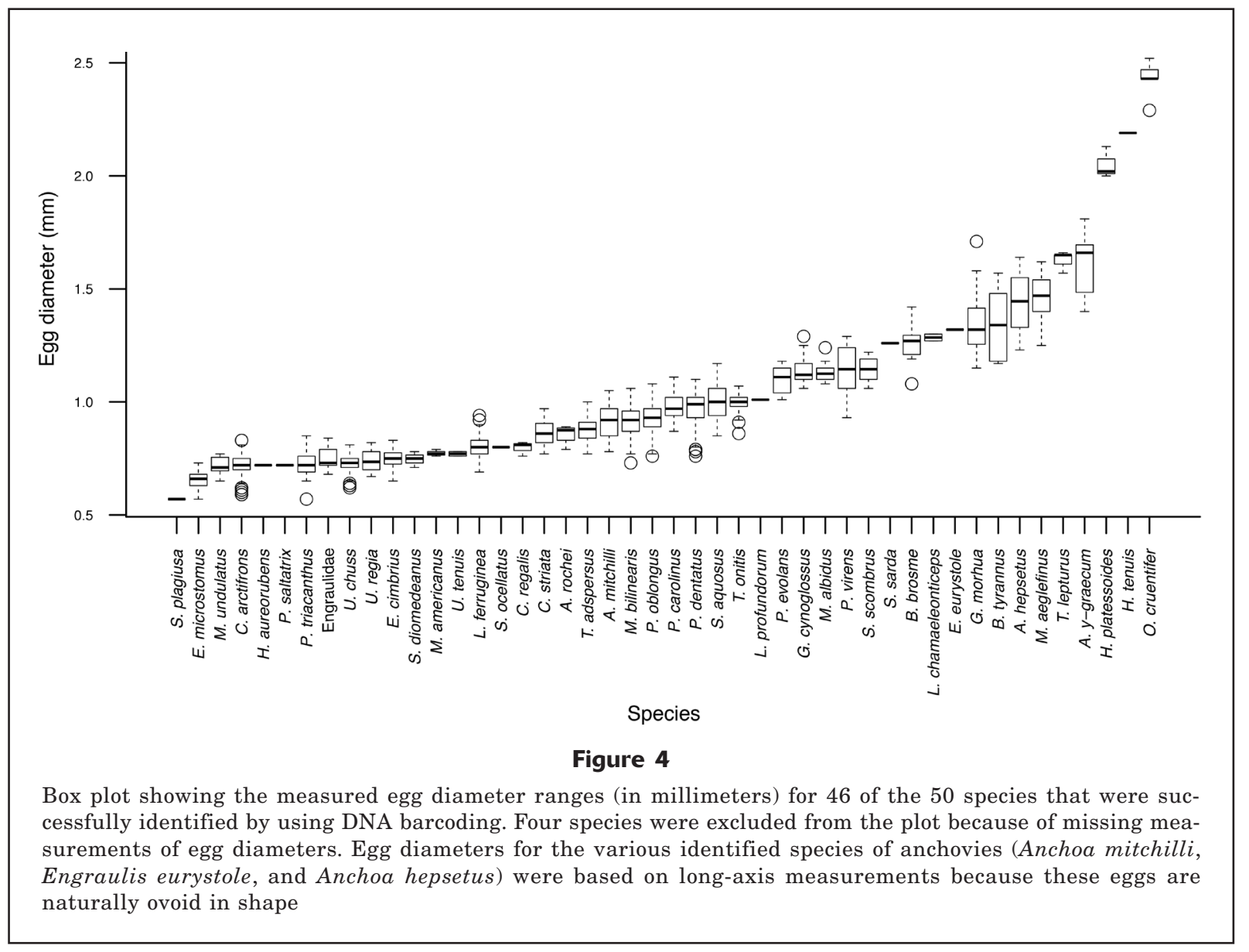

In general, the morphological identification of fish eggs has been problematic; therefore, the diversity of species subject to egg monitoring has been very limited. For example, the daily egg production method has been used successfully to estimate the biomass of a number of clupeoid fishes as well as Atlantic mackerel (Scomber scombrus) (Alheit, 1993; Priede and Watson, 1993; Stratoudakis et al., 2006). However, these successes have been limited taxonomically, and, for other species, substantial technical problems have emerged.

In an effort to compare 2 independent estimates of seasonal egg production and mortality for Atlantic cod and haddock on Georges Bank, Lough et al. (2008) stated directly that the early egg stages of both species are indistinguishable from one another and, furthermore, that estimates of early-stage egg abundance based on extrapolations of morphological identifications of late-stage eggs are likely inaccurate-stressing the need for improved spawning ground mapping with the development of DNA-based identification techniques. Similarly, in the Irish Sea, the use of TaqMan DNA technology confirmed the overestimation of cod egg abundance due to an extremely high rate of morphology-based misidentifications of "cod-like" eggs (Fox et al., 2005). In lower latitudes, where species diversity is much higher, the breadth of these problems is even more striking and the morphological identification of fish eggs is most often not even attempted (Kendall and Matarese, 1994).

Although the cost of DNA barcoding has decreased in recent years (Richardson et al., 2007), the cost per sample still presents an issue-especially for largescale monitoring programs, such as ichthyoplankton surveys. For programs without any internal capabilities, the cost of having the molecular identification performed by an outside group is currently $\$ 14-20$ per sample, for all steps in the process. For our program, performing this work internally would have required initial expenses to purchase equipment and set up laboratory space, reoccurring annual expenses to hire staff and maintain equipment, and the standard per sample expenses for reagents. The cost of doing the work internally would, therefore, have far exceeded the costs of working with an external partner-a pattern we expect would hold for most monitoring programs. The subsampling procedure we have developed is one means of reducing total barcoding cost. The development of an automated egg measuring tool based on image analysis software allowed us to optimize our sampling. Although we did not target a specific taxon in our sampling, such a direction is possible if DNA barcoding is combined with an efficient subsampling tool to target specific 


\section{Table 2}

Results from the analysis of the effect of temperature on egg diameter for barcoded fish species that were identified from at least 15 stations in the northeastern U.S. continental shelf between Cape Hatteras, North Carolina, and Nova Scotia, Canada. Both $P$-values and the coefficient of determinations $\left(r^{2}\right)$ were calculated with linear regression analysis of SST versus measured egg diameter (in millimeters). Species that displayed a significant trend between SST and egg diameter $(P<0.05$ or $5 \%)$ are indicated with an asterisk and are visually illustrated in Figure 5, A-E.

\begin{tabular}{lcccc}
\hline Species & \multicolumn{5}{c}{$\begin{array}{c}\text { Number of } \\
\text { stations }\end{array}$} & $P$ & $r^{2}$ \\
\hline Hippoglossina oblonga * & 184 & 72 & $<0.0001$ & 0.2335 \\
Merluccius bilinearis & 196 & 59 & 0.1901 & 0.0100 \\
Urophycis chuss & 144 & 53 & 0.3175 & 0.0070 \\
Citharichthys arctifrons & 153 & 45 & 0.0438 & 0.0300 \\
Scophthalmus aquosus & 81 & 29 & 0.8347 & 0.0006 \\
Peprilus triacanthus * & 52 & 22 & $<0.0001$ & 0.5083 \\
Limanda ferruginea $^{*}$ & 80 & 22 & 0.0012 & 0.1277 \\
Enchelyopus cimbrius & 35 & 19 & 0.1160 & 0.0732 \\
Tautogolabrus adspersus & 45 & 17 & 0.2615 & 0.0322 \\
Paralichthys dentatus & 50 & 16 & 0.0920 & 0.0580 \\
Gadus morhua * & 47 & 15 & $<0.0001$ & 0.4951 \\
& & & & \\
\hline
\end{tabular}

species. This combination could make this approach a more cost-efficient one for small-scale projects.

Although other lower-cost techniques for molecular identification do exist, most of them are limited in regard to research scope. Hyde et al., (2005) successfully implemented multiplex PCR onboard a research vessel to identify fish eggs and larvae in real time; however, this approach is best-suited for identifications of 5-20 species at a time. Alternatively, the use of multiplex suspension bead arrays for the identification of fish eggs is lower in cost than DNA barcoding and similar in its high-throughput capability, but this technique can identify an egg only if a probe for that species is included in the array (Gleason and Burton, 2012)-a restriction that is not encountered with DNA barcoding. Where our specific approach to molecular identification falls short is that it is not suitable for use with formalin-preserved eggs, which are easier to stage than ethanol-preserved eggs. Applications, such as the daily egg production method, that require the ability to resolve egg stages, would benefit greatly with the ability to use formalin-preserved samples. Certain molecular identification approaches, targeted at specific species, have been successfully applied to formalin material (Goodsir et al., 2008), and techniques with DNA barcoding on shorter fragments and formalin-preserved material are being developed (Zhang, 2010).

Looking forward, a DNA-barcoding approach could be implemented in a wide range of ichthyoplankton studies in addition, and in relation, to the identification of fish eggs. In comparison with fish larvae, eggs provide a more precise documentation of spawning location and time. For Atlantic cod in particular, the potential use of DNA barcoding of fish eggs is notable. Atlantic cod in U.S. waters comprise at least 3 genetic stocks, each thought to have further substock diversity associated with specific spawning grounds and seasons (Kovach et al., 2010; Zemeckis et al., 2014). It also has been suggested that other spawning stocks in the eastern Gulf of Maine exist, although this area has been so depleted that it is unknown if spawning persists there (Ames, 2004). We found differences in egg size that were associated with temperature, which in turn was associated with season and region of collection. A more extensive sampling procedure would likely reveal further complexity.

Although DNA barcoding is insufficient for distinguishing among stocks, the laboratory procedures do provide an extensive time-series archive of DNA, allowing the identification of spawning components in future molecular studies. In regard to indices of spawning stock biomass, where problems have arisen in the past as a result of morphologically based misidentifications, DNA barcoding could be used to broaden the use of existing surveys, while bypassing the assumption of constant egg mortality that underlies the use of larval abundances as indices of spawning stock biomass.

Overall, we have shown that DNA barcoding of fish eggs is sufficiently advanced to be incorporated into long-term, regional-scale ichthyoplankton monitoring programs. Trial runs with unidentified, well-digested fishes obtained from stomach samples collected during an ongoing food habits monitoring program (Smith and Link, 2010) show similar promise (Lewis and 

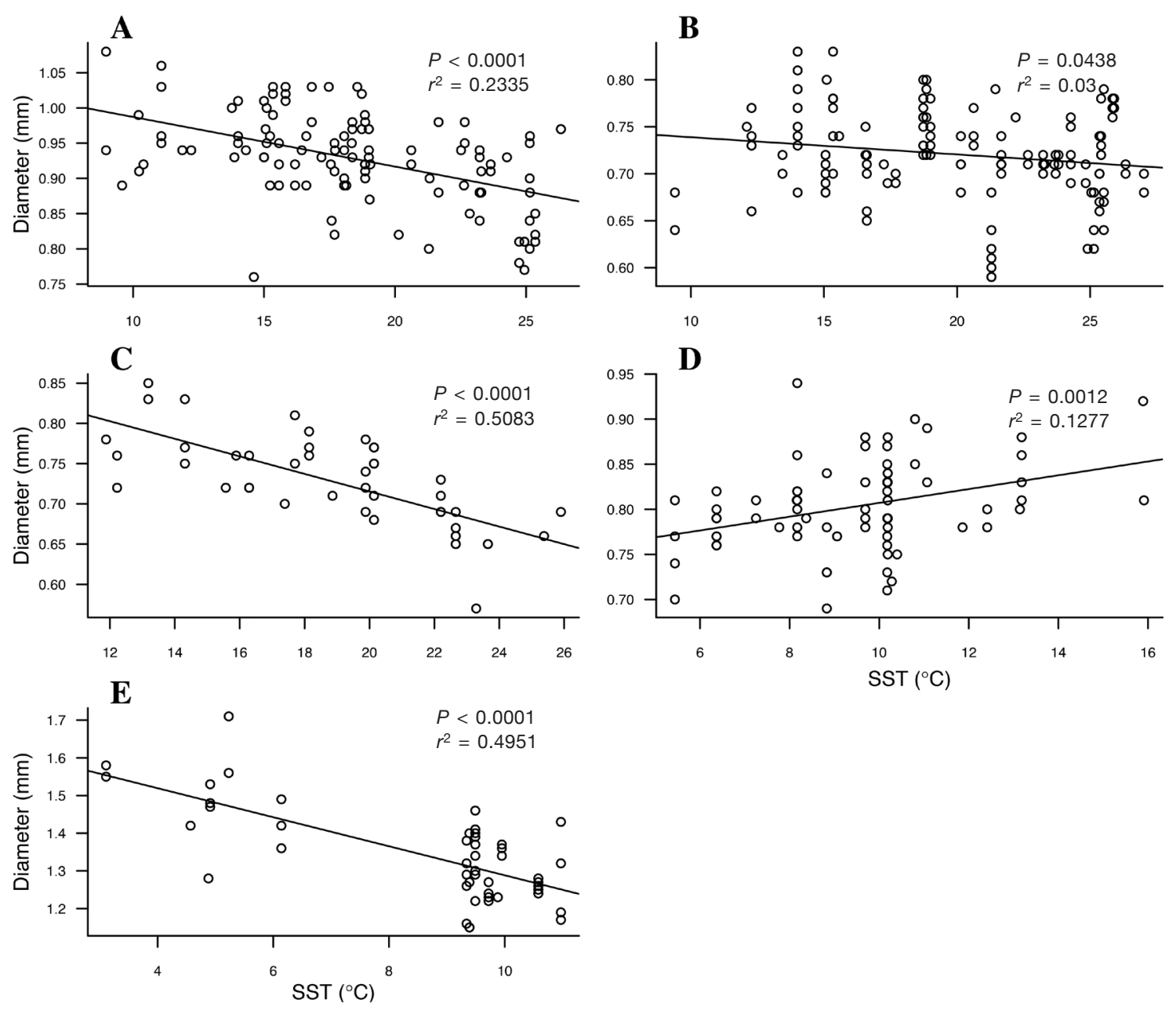

Figure 5

Scatter plots and linear regression analysis results for the 5 identified species, collected from at least 15 stations along the northeastern U. S. continental shelf during 2002-2012, for which a significant trend $(P<0.05$ or $5 \%)$ was observed between egg diameter (measured in millimeters) and sea-surface temperature (SST) of the collection day (in degrees Celsius): (A) fourspot flounder (Hippoglossina oblonga), (B) Gulf Stream flounder (Citharichthys arctifrons), (C) butterfish (Peprilus triacanthus), (D) yellowtail flounder (Limanda ferruginea), and (E) Atlantic cod (Gadus morhua). Each measured diameter is marked with an open circle, and a solid line illustrates the overall trend observed. The calculated $P$-value and the coefficient of determination $\left(r^{2}\right)$ for each species are included in the top-right corner of each plot.

Smith ${ }^{4}$ ). Currently, many large organizations, such as the National Marine Fisheries Service, handle molecular identification on a program-specific basis, each of which may use a different technique. The consequence of this fractured approach is a substantial redundancy in cost, effort, and equipment across programs. Additionally, many smaller programs are unable to justify the start-up and reoccurring costs of a molecular laboratory and, therefore, continue to produce data with a substantial fraction of individual specimens not identi-

\footnotetext{
${ }^{4}$ Lewis, L., and B. Smith. 2013. Unpubl. data. Northeast Fish. Sci. Cent., Natl. Mar. Fish. Serv., NOAA, Narragansett, RI, and Woods Hole, MA.
}

fied at the species level. The opportunity presented by DNA barcoding changes this fractured and inefficient approach to molecular identification into one unified method that can be shared across regions and types of sampling programs.

\section{Acknowledgments}

We thank the scientists and crew of the research vessels, too many to name individually, who contributed to the collection of ichthyoplankton samples over several decades, and in particular J. Prezioso, who ensured that additional ethanol-preserved samples were collect- 
ed over the past decade. We especially thank all the scientists and technicians at the Canadian Center for DNA Barcoding at the University of Guelph (Guelph, Ontario, Canada) for analytical support and A. Bucklin (University of Connecticut, Groton, Connecticut) and N. Copley (Woods Hole Oceanographic Institution, Woods Hole, Massachusetts) for the use of fish eggs from additional archived samples.

\section{Literature cited}

Ahlstrom, E. H., and H. G. Moser.

1980. Characters useful in identification of pelagic marine fish eggs. CalCOFI Rep. XXI:121-131.

Alheit, J.

1993. Use of the daily egg production method for estimating biomass of clupeoid fishes: a review and evaluation. Bull. Mar. Sci. 53:750-767.

Ames, E. P.

2004. Atlantic cod stock structure in the Gulf of Maine. Fisheries 29:10-28. Article

Carreon-Martinez, L. B., S. A. Holt, B. S. Nunez, C. K. Faulk, and G. J. Holt.

2010. The use of polymerase chain reaction for the identification of sciaenid eggs. Mar. Biol. 157:1889-1895. Article

Chambers, R. C., and W. C. Leggett.

1996. Maternal influences on variation in egg sizes in temperate marine fishes. Am. Zool. 36:180-196. Article

Conway, D. V. P., S. H. Coombs, and C. Smith

1997. Vertical distribution of fish eggs and larvae in the Irish Sea and southern North Sea. ICES J. Mar. Sci. 54:136-147. Article

Fox, C. J., M. I. Taylor, R. Pereyra, M. I. Villasana, and C. Rico. 2005. TaqMan DNA technology confirms likely overestimation of cod (Gadus morhua L.) egg abundance in the Irish Sea: implications for the assessment of the cod stock and mapping of spawning areas using egg-based methods. Mol. Ecol. 14:879-884. Article

Gleason, L. U., and R. S. Burton.

2012. High-throughput molecular identification of fish eggs using multiplex suspension bead arrays. Mol. Ecol. Resour. 12:57-66. Article

Goodsir, F., M. J. Armstrong, P. R. Witthames, D. L. Maxwell, and C. J. Fox.

2008. The use of species-specific TaqMan probes for identifying early stage gadoid eggs following formaldehyde fixation. ICES J. Mar. Sci. 65:1573-1577. Article

Hajibabaei, M., J. R. deWaard, N. V. Ivanova, S. Ratnasingham, R. T. Dooh, S. L. Kirk, P. M. Mackie, and P. D. N. Hebert.

2005. Critical factors for assembling a high volume of DNA barcodes. Philos. Trans. R. Soc. Lond., B 360: 1959-1967. Article

Hebert, P. D. N., A. Cywinska, S. L. Ball, and J. R. deWaard. 2003a. Biological identifications through DNA barcodes. Proc. R. Soc., B 270:313-321. Article

Hebert, P. D. N., S. Ratnasingham, and J. R. de Waard.

2003b. Barcoding animal life: cytochrome $c$ oxidase subunit 1 divergences among closely related species. Proc. R. Soc., B 270(suppl 1):S96-S99. Article

Hiemstra, W. H.

1962. A correlation table as an aid for identifying pelagic fish eggs in plankton samples. J. Cons. Int. Explor. Mer 27:100-108. Article
Hyde, J. R., E. Lynn, R. Humphreys Jr., M. Musyl, A. P. West, and R. Vetter.

2005. Shipboard identification of fish eggs and larvae by multiplex PCR, and description of fertilized eggs of blue marlin, shortbill spearfish, and wahoo. Mar. Ecol. Prog. Ser. 286:269-277. Article

Ivanova, N. V., E. L. Clare, and A. B. Borisenko.

2012. DNA barcoding in mammals. Analytical protocols. In DNA barcodes: methods in molecular biology (W. J. Kress and D. L. Erickson, eds), p. 153-182. Humana Press, Totowa, NJ.

Kendall, A. W., Jr., and A. C. Matarese.

1994. Status of early life history descriptions of marine teleosts. Fish. Bull. 92:725-736.

Kovach, A. I., T. S. Breton, D. L. Berlinsky, L. Maceda, and I. Wirgin.

2010. Fine-scale spatial and temporal genetic structure of Atlantic cod off the Atlantic coast of the USA. Mar. Ecol. Prog. Ser. 410:177-195. Article

Kucera, C. J., C. K. Faulk, and G. J. Holt.

2002. The effect of spawning salinity on eggs of spotted seatrout (Cynoscion nebulosus, Cuvier) from two bays with historically different salinity regimes. J. Exp. Mar. Biol. Ecol. 272:147-158. Article

Lough, R. G., L. O'Brien, and L. J. Buckley.

2008. Differential egg mortality of Georges Bank cod and haddock inferred from two independent estimates of seasonal egg production. J. Northwest Atl. Fish. Sci. 41:119-128. Article

Marteinsdottir, G., and G. A. Begg.

2002. Essential relationships incorporating the influence of age, size and condition on variables required for estimation of reproductive potential in Atlantic cod Gadus morhua. Mar. Ecol. Prog. Ser. 235:235-256. Article

Marteinsdottir, G., and A. Steinarsson.

1998. Maternal influence on the size and viability of Iceland cod Gadus morhua eggs and larvae. J. Fish. Biol. 52:1241-1258. Article

Ouellet, P., Y. Lambert, and M. Castonguay.

1997. Spawning of Atlantic cod (Gadus morhua) in the northern Gulf of St. Lawrence: a study of adult and egg distributions and characteristics. Can. J. Fish. Aquat. Sci. 54:198-210. Article

Priede, I. G., and J. J. Watson.

1993. An Evaluation of the daily egg production method for estimating biomass of Atlantic mackerel (Scomber scombrus). Bull. Mar. Sci. 53:891-911.

Ratnasingham, S., and P. D. N. Hebert.

2007. BOLD: The Barcode of Life Data System (website). Mol. Ecol. Notes 7:355-364. Article

Richardson, D. E., J. D. Vanwye, A. M. Exum, R. K. Cowen, and D. L. Crawford.

2007. High-throughput species identification: from DNA isolation to bioinformatics. Mol. Ecol. Notes 7:199-207. Article

Richardson, D. E., J. K. Llopiz, K. D. Leaman, P. S. Vertes, F. E. Muller-Karger, and R. K. Cowen.

2009. Sailfish (Istiophorus platypterus) spawning and larval environment in a Florida Current frontal eddy. Prog. Oceanogr. 82:252-264. Article

Richardson, D. E., J. A. Hare, W. J. Overholtz, and D. L. Johnson.

2010a. Development of long-term larval indices for Atlantic herring (Clupea harengus) on the northeast US continental shelf. ICES J. Mar. Sci. 67:617-627. Article 
Richardson, D. E., J. K. Llopiz, C. M. Guigand, and R. K. Cowen.

2010b. Larval assemblages of large and medium-sized pelagic species in the Straits of Florida. Prog. Oceanogr. 86:8-20. Article

Saitou, N., and M. Nei.

1987. The neighbor-joining method: a new method for reconstructing phylogenetic trees. Mol. Biol. Evol. 4:406-425.

Shao, K.-T., K.-C. Chen, and J.-H. Wu.

2002. Identification of marine fish eggs in Taiwan using light microscopy, scanning electric microscopy and mtDNA sequencing. Mar. Freshw. Res. 53:355-365. Article

Smith, B. E., and J. S. Link.

2010. The trophic dynamics of 50 finfish and 2 squid species on the northeast US continental shelf. NOAA Tech. Memo. NMFS-NE-216, 640 p.

Stratoudakis, Y., M. Bernal, K. Ganias, and A. Uriarte. 2006. The daily egg production method: recent advances, current applications and future challenges. Fish Fish. 7:35-57. Article

Valdez-Moreno, M., L. Vásquez-Yeomans, M. Elías-Gutiérrez, N. V. Ivanova, and P. D. N. Hebert.

2010. Using DNA barcodes to connect adults and early life stages of marine fishes from the Yucatan Peninsula, Mexico: potential in fisheries management. Mar. Freshw. Res. 61:655-671. Article

Ward, R. D., T. S. Zemlak, B. H. Innes, P. R. Last, and P. D. N. Hebert.

2005. DNA barcoding Australia's fish species. Philos. Trans. R. Soc. Lond., B 360:1847-1857. Article

Zeldis, J. R.

1993. Applicability of egg surveys for spawning-stock biomass estimation of snapper, orange roughy, and hoki in New Zealand. Bull. Mar. Sci. 53:864-890.

Zemeckis, D. R., D. Martins, L. A. Kerr, and S. X. Cadrin. 2014. Stock identification of Atlantic cod (Gadus morhua) in US waters: an interdisciplinary approach. ICES J. Mar. Sci. 71:1490-1506. Article

Zemlak, T. S., R. D. Ward, A. D. Connell, B. H. Holmes, and P. D. N. Hebert.

2009. DNA barcoding reveals overlooked marine fishes. Mol. Ecol. Resour. 9:237-242. Article

Zhang, J.

2010. Exploiting formalin-preserved fish specimens for resources of DNA barcoding. Mol. Ecol. Resour. 10: 935941. Article 